\title{
Modeling of Novel Microfluidic based Flow Sensor Inspired from Fish Canal Neuromast for Underwater Sensing
}

\author{
Mohd Norzaidi Mat Nawi ${ }^{\mathrm{a}^{*}}$, Asrulnizam Abd Manaf ${ }^{\mathrm{a}, \mathrm{b}}$, Mohd Rizal Arshad ${ }^{\mathrm{a}}$, Othman Sidek ${ }^{\mathrm{b}}$ \\ anderwater Robotics Research Group (URRG), School of Electrical and Electronic Engineering, \\ ${ }^{b}$ Collaborative microelectronic Design Excellence Center (CEDEC), Engineering Campus, Universiti Sains Malaysia, 14300 Nibong Tebal, Pulau Pinang, \\ Malaysia
}

*Corresponding author: norzaidiurrg@gmail.com

\section{Article history}

Received :19 December 2012

Received in revised form :

21 February 2013

Accepted :15 April 2013

\section{Graphical abstract}

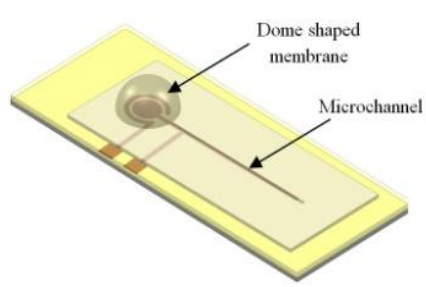

\begin{abstract}
Modeling of the novel microfluidic based flow sensor inspired from the canal neuromast in the fish lateral line system has been presented in this paper. The structure of the sensor consisted of the dome-shaped membrane and integrated with the microchannel which was filled with electrolyte. The analysis on the model was carried out using the computational fluid dynamic and finite element method. Based on the simulation, high performance of this sensor can be achieved by increasing the radius and decreasing the ratio of the radius of the dome-shaped membrane. The dome with $2.5 \mathrm{~mm}$ radius and 1.01 ratios was chosen due to the maximum response for the drag force and displacement based on the velocity input. The PDMS material which has lowers of Young Modulus was suggested to be used as a membrane. The microfluidic technology was proposed as a sensing element due to the simple structure and easy to be fabricated compare to the common sensing element such as piezoresistive and strain gage. The different electrolytes such as methanol, ethanol, water and propylene carbonate were simulated in order to study the effect of using different electrolytes to the performance of the microchannel. The methanol which has low viscosity and low surface tension was proposed to be used as an electrolyte for this sensor.
\end{abstract}

Keywords: Microfluidic based flow Sensor; canal neuromast; underwater sensing

\begin{abstract}
Abstrak
Permodelan pengesan aliran berasaskan mikro bendalir yang baru telah diilhamkan dari neuromast terusan dalam sistem garis sisi ikan telah diperihalkan dalam artikel ini. Struktur pengesan yang terdiri daripada membran berbentuk kubah dan disepadukan dengan saluran mikro yang diisi dengan elektrolit. Analisis ke atas model telah dijalankan menggunakan pengiraan dinamik bendalir dan kaedah unsur terhingga. Berdasarkan simulasi, prestasi tinggi pengesan ini boleh dicapai dengan meningkatkan jejari dan mengurangkan nisbah jejari membran yang berbentuk kubah. Kubah dengan jejari $2.5 \mathrm{~mm}$ dan nisbah 1,01 telah dipilih kerana respons yang maksimum untuk daya seretan dan anjakan berdasarkan kemasukan halaju. Bahan PDMS yang mempunyai nilai Young Modulus yang lebih rendah telah dicadangkan untuk dilaksanakan sebagai membran. Penggunaan teknologi mikro bendalir telah dicadangkan sebagai elemen pengesan disebabkan oleh strukturnya yang ringkas dan mudah untuk difabrikasi berbanding dengan elemen pengesan yang biasa seperti piezoresistive dan tolok tekanan. Elektrolit yang berbeza seperti metanol, etanol, air, dan propylene carbonate telah di simulasi untuk mengkaji kesan menggunakan elektrolit berbeza kepada prestasi saluran mikro. Metanol yang mempunyai kelikatan dan ketegangan permukaan yang rendah dicadangkan untuk digunakan sebagai elektrolit untuk pengesan ini.
\end{abstract}

Kata kunci: Pengesan aliran berasaskan mikro bendalir; canal neuromast; pengesanan bawah air

(C) 2013 Penerbit UTM Press. All rights reserved.

\subsection{INTRODUCTION}

The underwater sensing has been increasingly explored several decades ago to be implemented on the underwater vehicle such as glider, autonomous underwater vehicle (AUV) and robotic. There are several types of underwater sensor including acoustic sensor, optical sensor and flow sensor. Recent advancement in the underwater sensor technology for the underwater application is reviewed and discussed by Arshad (2009). Recently, many developments and improvement has been done for the flow sensor in order to miniaturize and to increase the performance of the sensor. There are two types of principles of the current 
conventional flow sensor already developed, namely thermal based hot wire anemometry and Doppler frequency shifts. The hot wire measures the fluid velocity by sensing changes of heat transfer meanwhile the Doppler measures the flow by shifting the frequency due to the flow motion. ${ }^{2,3}$ However, the general size of the previous conventional flow sensor is generally large and not suitable to form an array especially for measuring the flow distribution. ${ }^{4}$ Therefore, the alternative sensing method which inspired from nature such as lateral line system in fish body has been studied in order to improve the performance and the size of the sensor. ${ }^{5}$ Fish depends on the lateral line system to form the hydrodynamic images for flow imaging that help the fish to determine the size, shape, identity and location of another animal. This sensory system can also provide the guidance to the animal for different environmental conditions including the absence of visual and highly turbulence condition. ${ }^{6}$ A lateral line system in fish body consists of two types of neuromast that is superficial neuromast and canal neuromast. Superficial neuromast directly exposed to the flow and canal neuromast exists in subepidermal canals. Generally, fishes that live in running or turbulent water tend to have many canal neuromast compared to the superficial neuromast which is suitable for the fish to live in the distilled water. Both of neuromasts are composed or hair cells to induce the neuron signal based on the gelatinous cupula movement. ${ }^{7}$ The development of the flow sensor based on artificial hair cell has been previously discussed where it is usually consists of single hair cell and integrated with piezoresistive or strain gage. ${ }^{8}$

The idea of novel microfluidic based flow sensor was inspired from the fish canal neuromast. In the biological canal systems, it has a dome-shaped gelatin cupula and sensory hair cells inside the cupula to sense the movement of the cupula. Based on this principle, we proposed the microfluidic based flow sensor which consisted of dome-shaped membrane and integrated with the microchannel. The electrolyte was used as a medium to transfer the movement of the membrane to the electrolyte movement inside the microchannel. The electrolyte changes inside the microchannel were measured using electrical double layer capacitance (EDLC) concept. In designing the sensor, it was important to study the several factors that affected the performance and miniaturize the sensor. For this paper, the several factors such as the material, dimension of the dome structure, microchannel parameter and also selection of electrolyte were simulated and discussed. Previously, the silicon material has been widely used in the development of the Microelectromechanical system (MEMS) because it is more practical for the microfabrication techniques such as etching process. However, recently the polymer material such as Polydimethylsiloxane (PDMS), polyimide and polyurethane has been found more compatible which can provide greater advantages especially in mechanical yield strain than silicon. Most of the polymer materials are easy to deform and it is suitable to be implemented as a membrane or smart skin for the sensor. ${ }^{9}$ Also, the implementation of the microchannel as a sensing element can improve the size and performance of the sensor. The microfluidic have advantages for the miniaturization of sensor, including lower costs in manufacturing, usage and disposal. Smaller microchannel will reduce the overall size of the device, also becomes more sensitive to the absorption. ${ }^{10}$ The performance of microchannel depends on the size of microchannel ${ }^{11}$ and the electrolyte inside the microchannel. The important properties such as low surface tension, and low viscosity were considered in the selection of electrolyte. The potential liquids are methanol, propylene carbonate and ethanol. ${ }^{12}$ In this paper, the modeling of microfluidic based flow sensor was discussed. The important parameter such as dimension and material was simulated using computational fluid dynamic (CFD) and finite element method
(FEM). A few electrolytes were chosen for the simulation and the suitable electrolyte was suggested for future work.

\subsection{DESIGN AND PRINCIPLE}

In this section, the design and principle of the microfluidic based flow sensor were discussed. As mentioned before, the canal neuromast has a dome-shaped gelatin cupula and sensory hair cells as a receptor to sense the movement of the cupula. The lateral line system and the shape of canal neuromast were shown in Figure 1(a). From the inspiration of the principal mechanism of canal neuromast, we proposed the sensor design for the microfluidic based flow. It consisted of a dome-shaped membrane and microchannel that was filled with electrolyte, as shown in Figure 1(b). When the fluid flow imparts the dome surface, the dome membrane will give some displacement and subsequently will move the electrolyte inside the microchannel. The sensing electrode with the implementation of EDLC concept will sense the movement of electrolyte inside the microchannel. The change of capacitance depends on the surface area of the electrode, where the capacitance value increases as the surface area increased.

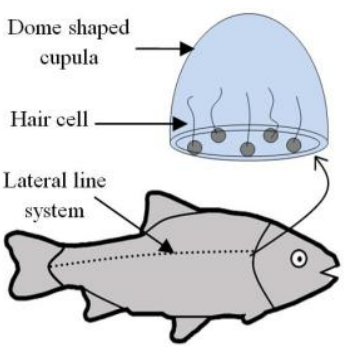

(a)

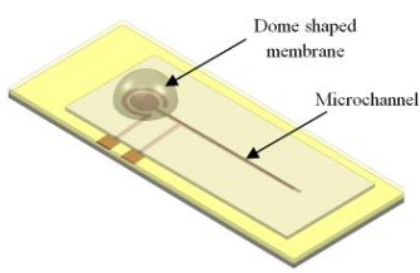

(b)
Figure 1 (a) The canal neuromast in the fish lateral line system; (b) The schematic structure for the microfluidic based flow sensor

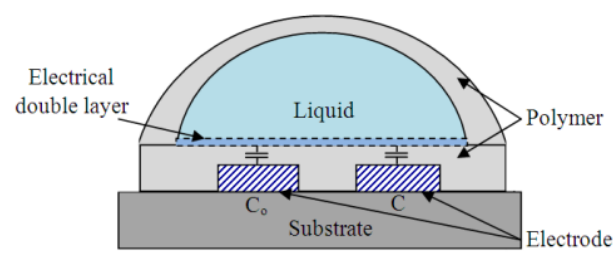

Figure 2 Cross sectional structure of the electrical double layer principle

The EDLC structure was shown in Figure 2 where it explained the formation of the ionic layer by the electrode. The behavior of ionic layer is similar to the conductor where the values depend on the thickness of the PDMS insulator layer and the permittivity of PDMS as discussed by a previous researcher Manaf et al. (2007). He also stated that the value of the capacitor in the absence of the electrolyte is equal to the value of the capacitance insulator because the air capacitance is too small and can be ignored based on the permittivity of the air layer. ${ }^{12}$ The concept of sensing based on the movement of electrolyte inside the microchannel which depended on the displacement of the dome was shown in Figure 3. The displacement of dome membrane, $\Delta x$ indicated the movement of electrolyte inside the microchannel where it changed the contact area of the electrode. The width of microchannel was fixed where only the length of 
microchannel was changed, $\Delta l$. Therefore, the resultant of capacitance changes based on area changes of the electrode was obtained in Eq. (3). At initial condition, the capacitance denotes as $C_{o}$. Given the capacitance changes at certain area was shown in equation (1), and the surface area in equation (2)

$$
\begin{aligned}
& C=\frac{\varepsilon S}{d} \\
& S=\pi r^{2}+w l \\
& \Delta C=C-C_{o}=\frac{\varepsilon w\left(l-l_{o}\right)}{d}
\end{aligned}
$$

where $\varepsilon, d, w, l, S$, and $r$ are the permittivity of polymer, thickness of the insulator, width, length, surface and radius of electrode, respectively.

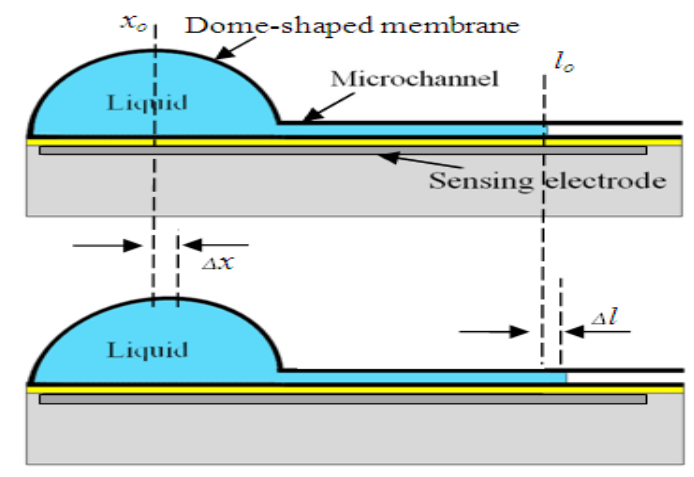

Figure 3 Sensing principle of the sensor

\subsection{METHODOLOGY}

In the methodology, the ANSYS (http://www.ansys.com) software was used to study the drag force acting on the dome surface, displacement of the membrane and the flow inside the microchannel. There were several modeling tools in ANSYS including ANSYS Mechanical APDL, ANSYS CFX and ANSYS FLUENT. For this study, they were divided into two analyses, dome-shaped membrane analysis and microchannel analysis. For the dome-shaped membrane analysis, the 3D dome-shaped membrane was modeled and meshed as shown in Figure 4. This model was analyzed for displacement of a membrane which depended on the fluid velocity, angle of flow applied to the dome, material of the membrane, and ratio between outer radius and inner radius of the dome.

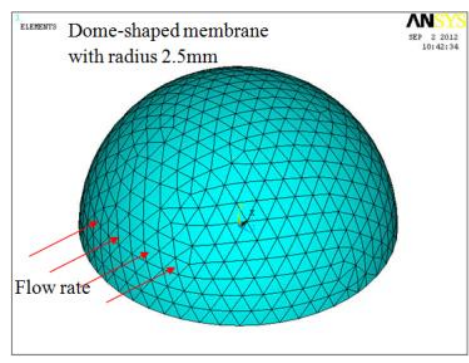

Figure 4 The 3D structure of dome shaped in ANSYS
For the applied fluid velocity, the Navier Stokes equation was used to calculate the drag force acting on the dome surface comprised of both viscous and inertial components using ANSYS FLUENT software. The dome-shaped cupula was governed by the equation of motion of viscous, incompressible, and Newtonian linear fluid

$$
\begin{aligned}
& \rho\left(\frac{\partial v}{\partial t}\right)+\nabla p-\mu \nabla^{2} v=0 \\
& \nabla \cdot v=0
\end{aligned}
$$

where $\rho$ is the fluid density, $\mathrm{v}$ is the fluid particle velocity, $\mathrm{p}$ is the pressure and $\mu$ is the dynamic viscosity of the fluid. For an incompressible fluid, the Navier-Stokes in Equation (4) was applied which the nonlinear convections term has been ignored. Equation (5) is the equation of continuity for an incompressible fluid. To obtain the displacement of the dome-shaped membrane, the result from the ANSYS FLUENT was transferred to the ANSYS Mechanical APDL. The different material was focused in this section and the important properties for each material such as density, elastic modulus and poisson's ratio were listed in Table 1. Deformations of dome membrane were supposed to force the fluid inside the microchannel to move at a certain length. Therefore, the selection of electrolyte also needed to be simulated and discussed. For the microchannel analysis, the different electrolyte such as ethanol, methanol, propylene carbonate and water were chosen in order to study the effect of viscosity to the performance of the sensor. Also, the different height of the microchannel (the same as width) was chosen. The ANSYS FLUENT was used to fulfill this study. The important properties including density and dynamic viscosity for each electrolyte was shown in Table 2.

Table 1 Mechanical property of polymer materials

\begin{tabular}{cccc}
\hline Material & $\begin{array}{c}\text { Density } \\
\left(\mathbf{k g} / \mathbf{m}^{3}\right)\end{array}$ & $\begin{array}{c}\text { Elastic } \\
\text { Modulus } \\
(\mathbf{M p a})\end{array}$ & $\begin{array}{c}\text { Poisson's } \\
\text { ratio }\end{array}$ \\
\hline Polyurethane & 1200 & 25 & 0.5 \\
PDMS & 920 & 0.75 & 0.5 \\
Polyimide & 1430 & 2500 & 0.34 \\
\hline
\end{tabular}

Table 2 Lists of properties for different electrolyte

\begin{tabular}{cccc}
\hline Electrolyte & $\begin{array}{c}\text { Kinematic } \\
\text { viscosity } \\
\left(\mathbf{m m}^{2} / \mathbf{s}\right)\end{array}$ & $\begin{array}{c}\text { Dielectric } \\
\text { Constant }\end{array}$ & $\begin{array}{c}\text { Boiling } \\
\text { point } \\
\left({ }^{\circ} \mathbf{C}\right)\end{array}$ \\
\hline Water & 0.89 & 80.10 & 99.98 \\
Methanol & 0.75 & 32.60 & 64.70 \\
$\begin{array}{c}\text { Propylene } \\
\text { Carbonate }\end{array}$ & 1.67 & 65.00 & 241.70 \\
Ethanol & 1.52 & 24.30 & 78.37 \\
\hline
\end{tabular}

\subsection{FINDING RESULTS AND DISCUSSION}

\subsection{Dome-Shaped Membrane Analysis}

Several parameters for dome-shaped membrane analysis were modified including outer radius and inner radius of the dome, material and angle of the fluid flow. At given fluid velocity, the 
sensor structure was optimized by considering the dome-shaped membrane displacement. Initially, the dome shaped with outer radius of $2.5 \mathrm{~mm}$, inner radius of $2.475 \mathrm{~mm}$ and thickness of microchannel $300 \mu \mathrm{m}$ was simulated using CFD software ANSYS FLUENT. The ratio of the radius which is outer radius, $R$ divided inner radius, $r$ was equaled to 1.01 . By assuming that the flow is laminar, the fluid velocity $0.1 \mathrm{~m} / \mathrm{s}$ was applied to the dome surface which parallel to the substrate and the distribution of pressure coefficient on the surface of the dome for different position can be observed as shown in Figure 5. The position of 0mm indicated the center of dome surface where the pressure was very low in this region. Figure 6 shows the pressure distribution on the dome surface and the direction of the applied flow in $\mathrm{x}$ direction. As we can see, the front surface gave high pressure due to the maximum velocity drop.

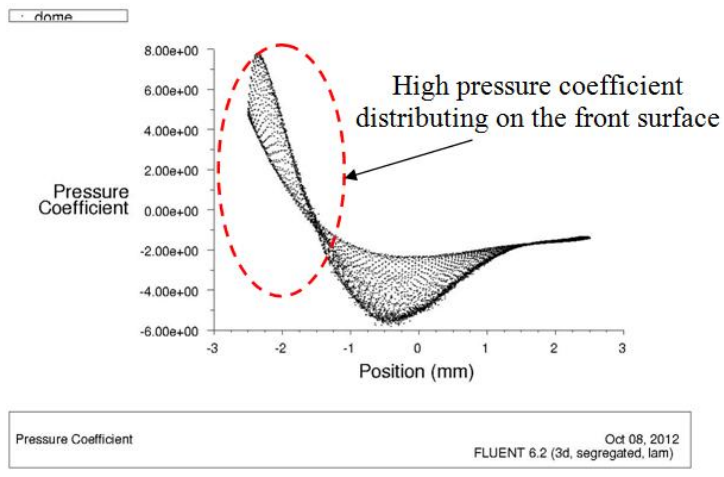

Figure 5 The distribution of pressure coefficient on the dome surface

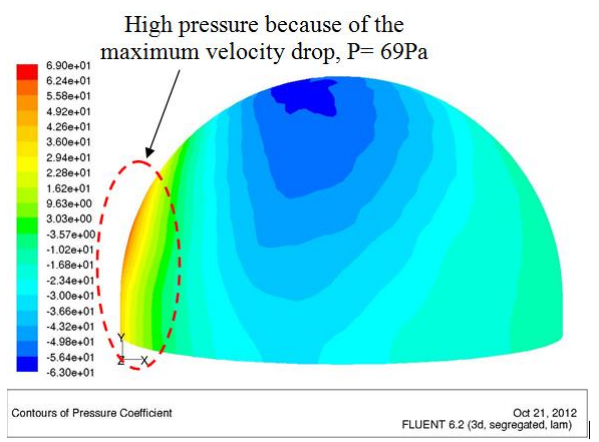

Figure 6 Pressure distributions for $0.1 \mathrm{~m} / \mathrm{s}$ with outer radius of $2.5 \mathrm{~mm}$

Next, the variation of mass flow rate or fluid velocity 0 to $1 \mathrm{~m} / \mathrm{s}$ was applied for different outer radius of $1.9 \mathrm{~mm}$ to $2.5 \mathrm{~mm}$. The input variation of mass flow rate was chosen based on the typical underwater flow measurement. The total drag force was equal to viscous and pressure force acting on the dome surface and it was obtained from the ANSYS FLUENT software. The drag force acting on the dome surface increased as the mass flow rate and the outer radius of the dome increased as shown in Figure 7. The big dome with $2.5 \mathrm{~mm}$ radius gave maximum drag force of about $2.7 \mathrm{mN}$. In this simulation, the leading edge effect of the sensor was ignored because the value was too small. Next, the simulation was done using different angles of flow starting $0^{\circ}$ until $90^{\circ}$. It is proved that different angle also affected to the value of drag force as shown in Figure 8. The value of drag force was depended on the surface area facing the flow. From the figure, the maximum surface area when the flow was in $90^{\circ}$ position, the surface area equaled to $2 \pi r^{2}$. For initial modeling, only zero angle of flow was considered where it faced one flow direction which is parallel to the substrate.

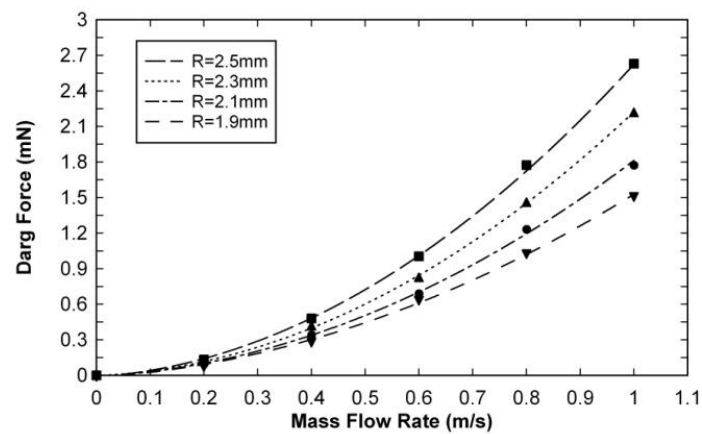

Figure 7 The drag force acting on the dome surface for different outer radius of the dome

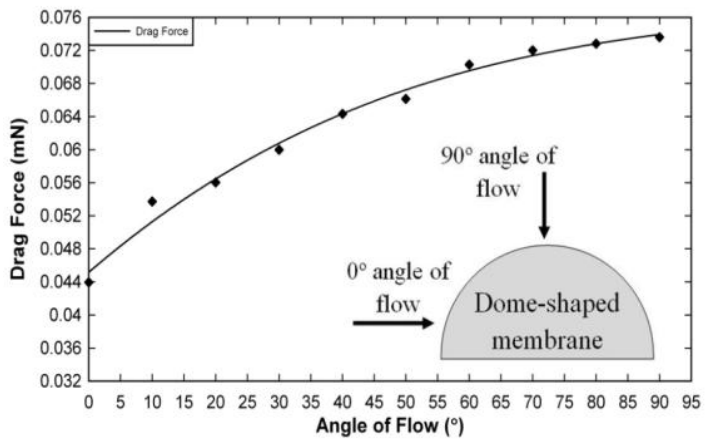

Figure 8 The drag force acting on the dome surface for different angles of flow

Results obtained from the CFD were substituted into the Finite element method tool that is ANSYS Mechanical APDL in order to study the displacement of the dome-shaped membrane. The different polymer materials such as PDMS, polyimide and polyurethane were selected due to their properties which suitable to be used as membranes that allow the displacement. The displacement of dome-shaped membrane was based on the mechanical properties of material where the material with lower Young Modulus led to high displacement. The flow velocity of $0.1 \mathrm{~m} / \mathrm{s}$ was applied for different material and different ratio of outer radius and inner radius $(\mathrm{R} / \mathrm{r})$. As shown in Figure 9, the PDMS material gave maximum displacement compared to polyimide and polyurethane. The displacement of dome-shaped membrane increased as the ratio of $\mathrm{R} / \mathrm{r}$ decreased and we can see that the maximum displacement was $0.6 \mu \mathrm{m}$ for ratio of 1.02 . Then, using the PDMS material, the different velocity of fluid with respect to the displacement using different ratios of the radius, it indicated the highest displacement for smallest ratio of radius as shown in Figure 10. However, the fabrication limitation needed to consider before selecting the suitable ratio for the dome-shaped membrane. The thin membrane frequently gave the high displacement, but it also can be easily torn during the fabrication process. Next, using the PDMS material, the displacement vector for the deformed shape of the membrane was plotted as shown in Figure 11 where the colors indicated the different values for the displacement distribution. From the figure, we can see that the shape that was facing the flow deformed at certain displacement which the base of the dome was fixed because it attached to the substrate. For the material using PDMS 
and fluid velocity was $0.1 \mathrm{~m} / \mathrm{s}$, the displacement equaled to $22 \mu \mathrm{m}$. From the ANSYS Mechanical APDL as well, other parameter can be obtained such as strain distribution on the dome surface. The limitation of the membrane can be estimated from the strain analysis and the limitation of the membrane due to membrane displacement can also be studied. Based on this simulation, the maximum strain did not exceed the value of Elastic modulus, so the membrane cannot be broken or failure.

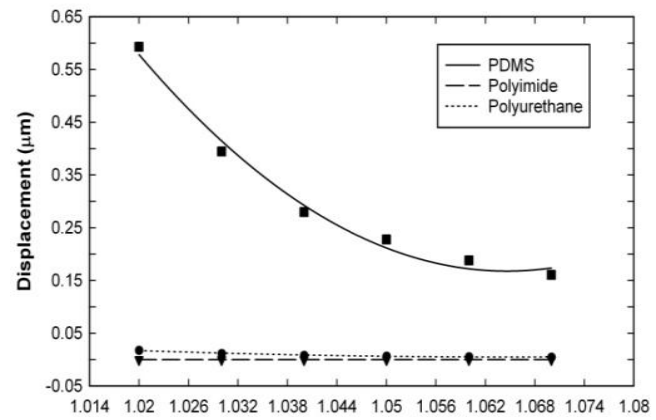

Figure 9 The performance of sensor for different material

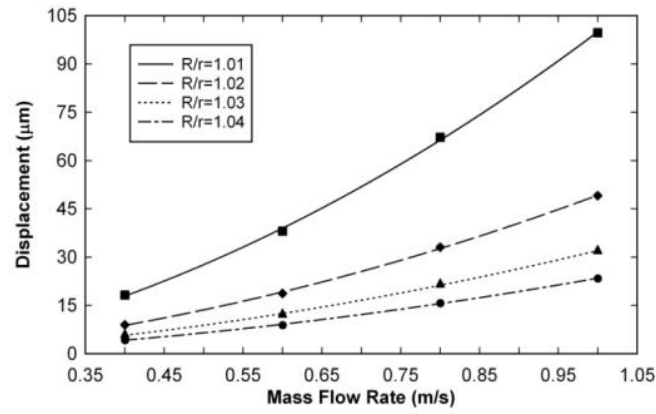

Figure 10 The performance of sensor for different ratio of outer and inner radius

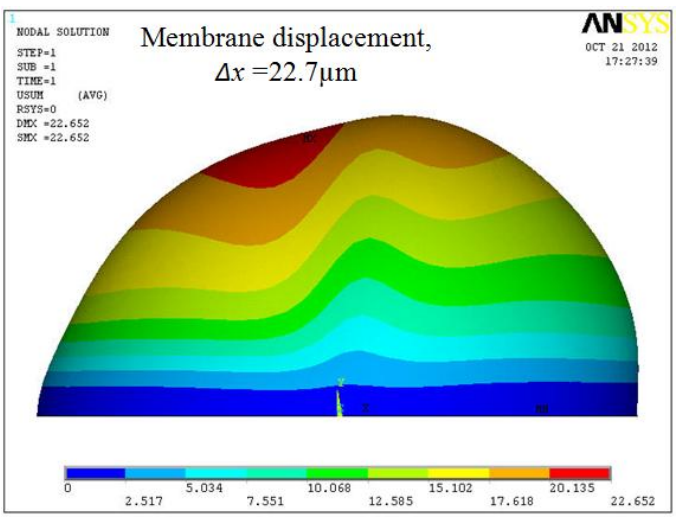

Figure 11 Displacement vector for $0.1 \mathrm{~m} / \mathrm{s}$ using PDMS material and ratio of 1.01

\subsection{Microchannel Analysis}

The electrolyte inside the microchannel will give the response based on the displacement of the dome-shape membrane. In other word, the inlet pressure inside the dome-shaped membrane will be increased and the electrolyte is forced to move at certain distances. Therefore, the fluid inside the microchannel is moved from the inlet to the outlet of the microchannel. Figure 12 shows the region of the fluid flow for $300 \mu \mathrm{m}$ height of the microchannel using liquid methanol. In order to study the effect of microchannel size, variation of height (similar as the width) $300 \mu \mathrm{m}$ until 1100 $\mu \mathrm{m}$ has been chosen to be simulated. It is assumed that the pressure difference between the inlet and outlet was $500 \mathrm{mPa}$ to allow the fluid flow inside the microchannel. Figure 13 shows the average velocity inside the microchannel for various heights of the microchannel. As predicted, the increasing height of the microchannel increased the velocity inside the microchannel. This could be due to the reduction of viscosity effect. The different microchannel height did not give major effect on the performance of the microchannel. It is assumed that the size of microchannel either large or small was not need to be concerned. However, in order to achieve the miniaturization of the sensor, small size of microchannel was required. Therefore, the smallest size of microchannel was suggested for the next analysis. The selection of electrolyte was also important in order to achieve the high efficiency of the sensor where the electrolyte with low surface tension will flow smoothly inside the microchannel. The surface tension was proportional to the viscosity which indicated that high kinematic viscosity gave high surface tension. Several different electrolytes were selected in this modeling including ethanol, propylene carbonate (pc) and water. The microchannel height was fixed to $300 \mu \mathrm{m}$. Figure 14 shows the velocity profile for different liquid where the position of 0 indicated the midsection of the microchannel. It is proven that the methanol has lowest surface tension because of the maximum velocity pattern compared to other liquids meanwhile the pc has the highest surface tension. In this case, the surface roughness of the wall of microchannel was neglected and assumed that the inner wall of PDMS was completely in wet condition.

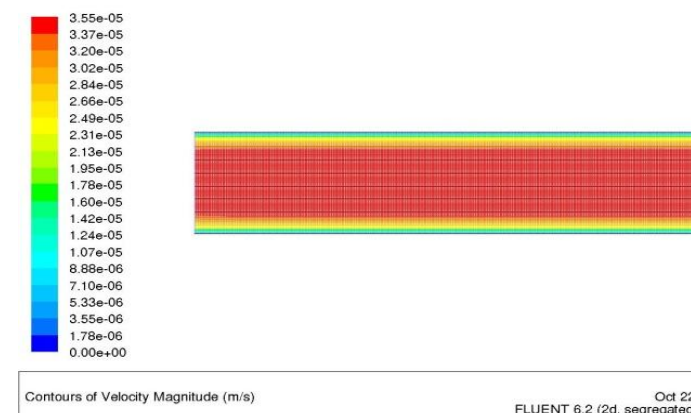

Figure 12 The average velocity for various heights of microchannel

The consideration parameters such as material of the sensor, ratio between inner and outer radius and the use of proper electrolyte were important to achieve high performance of the sensor and can reduce the overall size. The final specification of the sensor was estimated after analysis and optimization processes conducted as shown in Table 3. The suitable electrolyte such as methanol allowed the liquid to flow smoothly inside the microchannel. However, methanol with low boiling point seemed to be easily evaporated as indicated in the Table 2 . The problem could be solved by using the propylene carbonate as it showed similar performance as methanol. ${ }^{12}$ Further experimental study is recommended to validate the simulation result. The theoretical on the dynamic behavior of the canal cupula (dome-shaped membrane) in the fish lateral line system has been presented by Netten (1991). He concluded that the canal radius, the amount of stiffness coupling, viscosity and density of the fluid that give the 
response to the fluid inside the canal. He also obtained the relationship between fluid velocity and displacement of domeshaped canal. ${ }^{13}$

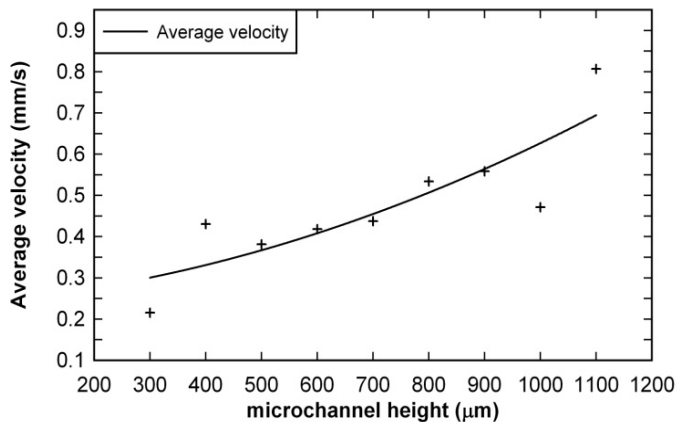

Figure 13 The velocity profile for different electrolyte

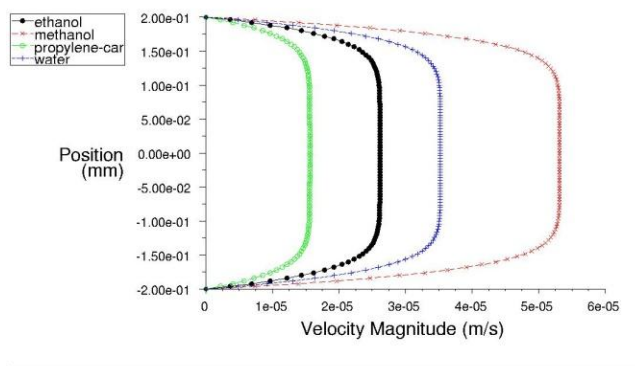

Velocity Magnitude

FLUENT 6.2 (2d, segregated, 22, lam)

Figure 14 The velocity profile for different electrolyte

Table 3 Final specification for the sensor

\begin{tabular}{ll}
\hline \multicolumn{1}{c}{ Parameter } & \multicolumn{1}{c}{ Value } \\
\hline Outer radius of dome, $R$ & $2.5 \mathrm{~mm}$ \\
Ratio radius of dome, $R / r$ & 1.01 \\
Height of dome, $h$ & $300 \mu \mathrm{m}+R$ \\
Microchannel dimension & $300 \mu \mathrm{m} \times 300 \mu \mathrm{m}$ \\
Length of microchannel & $12 \mathrm{~mm}$ \\
\hline
\end{tabular}

\subsection{CONCLUSION}

The microfluidic based flow sensor with different ratios of radius and material was successfully studied. By using the computational fluid dynamic and finite element method, it has proved that the different ratio of radius and different types of materials of domeshaped has a significant effect to the displacement of the dome. Highest performances of the sensor were achieved by increasing the outer radius of the dome and decreasing the ratio between inner and outer of the dome. Also, by using a lower elastic modulus material such as PDMS, maximum performances can be achieved. The flow sensor with $2.5 \mathrm{~mm}$ outer radius gave the maximum drag force equal to $2.7 \mathrm{mN}$ for $1 \mathrm{~m} / \mathrm{s}$ input fluid velocity. The smallest ratio 1.01 was suggested for future fabrication based on maximum displacement of the dome-shaped membrane. The PDMS polymer which gave the maximum displacement was the proposed material which easy to deform. Another advantage of the microfluidic based flow sensor was that it can measure the flow changes in multi direction where it depended on the flow of angle and it cannot break of fail during measurement. From the study, it is proposed that the methanol can be used as an electrolyte to fill in the dome container and microchannel because it gave maximum response based on the simulation.

\section{Acknowledgement}

The author is a USM fellowship holder. This study was supported by short term grant number 304/PELECT/60310023 and grant number 1001/PELECT/814168. The authors also would like to thank all members of Underwater Robotic Research Group (URRG), USM and School of Electrical and Electronics Engineering for their support and assistance throughout the work

\section{References}

[1] M. R Arshad. 2009. Recent Advancement in Sensor Technology for Underwater Applications. Ind. Journal Mar. Sci. 38: 267-273.

[2] T. Ebefors, E. Kalvesten, G. Stemme. 1998. Three Dimensional Silicon Triple-hot-wire Anemometer based on Polyimide Joints. In: Proceedings of the IEEE MEMS'98, Heidelberg, Germany, Jan 25-29. 93-98.

[3] Y. Takeda. 1986. Velocity Profile Measurement by Ultrasound Doppler Shift Method. Int. J. of Heat and Fluid Flow. 7: 313-318.

[4] J. Chen, Z. Fan and J. Zou. 2003. Two-dimensional Micromachined Flow Sensor Array for Fluid Mechanics Studies. J. Aerosp. Eng. 16: 85-97.

[5] J. Tao and X Yu. 2012. Hair Flow Sensors: From Bio-Inspiration To BioMimicking-A Review. Smart Materials and Structures. 21: 1-23.

[6] S. Coombs. 2001. Smart Skins: Information Processing by Lateral Line Flow Sensors. Auton Robot. 11: 255-261.

[7] J. Engelmann, W. Hanke, H. Bleckmann. 2002. Lateral Line Reception in Still- and Running Water. J. of Com. Physi. 188: 513-526.

[8] M. N. Mat Nawi, A. A Manaf, M. R Arshad, O Sidek. 2011. Review of MEMS Flow Sensors Based on Artificial Hair Cell Sensor. Journal of Microsystem Technologies. 17(9): 1417-1426.

[9] C. Liu. 2007. Recent Developments in Polymer MEMS. Advance Materials. 19: 3783-3790.

[10] J. C. McDonald, D. C. Duffy, J. R. Anderson, D. T. Chiu, H. Wu, O. J. Schueller, G. M. Whitesides. 2000. Fabrication of microfluidic Systems in Poly(dimethylsilaxone). Electrophoresis. 21: 27-40.

[11] M. F. A. Rahman, M. R. Arshad, A. A. Manaf, O. Sidek. 2012. The Effect of Different Parameter on the Flow Response of MicrofluidicBased Acoustic Sensor. Procedia Engineering. 41: 230-236.

[12] A. A Manaf, K. Namakura and Y. Matsumoto. 2007. One-SideElectrode-Type Fluid-Based Inclinometer Combined with CMOS circuitry. Sensors and Materials. 19: 417-434.

[13] S. M. Netten. 1991. Hydrodynamic of the Excitation of the Cupula in the Fish Canal Lateral Line. J. Acoust. Soc. Am. 89: 310-319. 